\title{
Sibs with Mental and Physical Retardation and Trichorrhexis Nodosa with Abnormal Amino Acid Composition of the Hair
}

\author{
R. J. POLLITT, ^ F. A. JENNER,^ and MARGARET DAVIES \\ From Medical Research Council Unit for Research on the Chemical Pathology of Mental Disorders, \\ Medical School, Birmingham 15; Hollymoor Hospital, Birmingham 31; \\ and Lea Castle Hospital, Wolverley, Nr. Kidderminster, Worcestershire
}

Trichorrhexis nodosa is a condition in which individual hairs develop areas where the shaft has split longitudinally into numerous small fibres. The hairs eventually break at these points leaving brush-like ends. Usually trichorrhexis nodosa results from mechanical trauma or harsh chemical treatment (Chernosky and Owens, 1966), but two inherited disorders, argininosuccinic aciduria (Allan et al., 1958; Levin, Mackay, and Oberholzer, 1961; Westall, 1960) and a type of sex-linked neurodegeneration (Menkes et al., 1962), are often associated with a very marked degree of trichorrhexis nodosa. This is a report of a brother and sister with another syndrome, showing mental and physical retardation, trichorrhexis nodosa, and other hair defects.

\section{Case Reports}

The two children are the second and third of a family of three. The parents were unrelated, and appear normal. The father, a farm worker, was born in 1936, and the mother in 1938. The mother's brother had Down's syndrome, but he died suddenly in 1965; no chromosome studies had been performed. The first child is a normal intelligent boy (N.C.) born in 1959.

Case 1. The second child (L.C.) was born in May 1961 ; her birthweight was $3.0 \mathrm{~kg}$., body length $48 \mathrm{~cm}$., and head circumference $33 \mathrm{~cm}$. The mother had toxaemia of pregnancy, a severe antepartum haemorrhage, and the labour and delivery were long and difficult; in addition the child is reported to have been severely jaundiced for 10 days after her birth. She was not noted to be abnormal until 1 year old, when she showed no signs of wanting to stand or walk. She was obviously retarded, and in addition her hair was sparse, stubbly, and brittle. Her nails were ill-shapen and spoon-like.

Received August 7, 1967.

* Present address: The University Department of Psychiatry, Whiteley Wood Clinic, Shefficld S10 3TL.
Her tongue was reported to have white plaques. She was at first thought to be suffering from the effects of cerebral anoxia at birth, which had caused brain damage, and the mother was therefore reassured about further pregnancies.

The patient was admitted for special studies in May 1966 aged 5 years. She was now a simple, fairly goodnatured child, with an obviously vacant expression. She looked perhaps three years younger than her age. She was affectionate, was walking, and was feeding herself, but remained incontinent. She weighed $15 \cdot 5$ $\mathrm{kg}$., her head circumference was $47 \mathrm{~cm}$., and her body length was $91 \mathrm{~cm}$.

No formal psychological testing was possible because of the short attention span. Her motor development was within the range of 18 months to 2 years. She had a wide-stanced gait, but could climb on to a chair. She could hold two cubes in one hand and return them to a container but not build with them. She could extend her arm to help when being dressed.

Her speech and understanding were at a level below that expected of a child aged 1 year. There was no recognizable speech.

She had short sparse eyebrows, and the scalp hair was 1-2 cm. long, except for areas cf alopecia caused by rubbing (Fig. 1a). Apparently the hair condition had been progressively deteriorating, though with short remissions, since she was about 1 year old. The hair had a matted appearance and there was a follicular hyperkeratosis of the scalp and forehead.

The hair itself could easily be broken and showed classical trichorrhexis nodosa (Fig. 2a). In addition the shaft was often flattened in cross-section and sometimes twisted slightly in the long axis (pili torti). The hair surface was irregular, and scanning electron micrographs showed that the normal pattern of scales was almost completely absent (Fig. 3). The high-angle $x$-ray diffraction pattern was normal, but electron-microscopical examination of stained sections has shown several abnormalities (Sikorski and Robson, 1968).

She had cold blue extremities indicating a defective peripheral circulation, but examination, including ECG, 


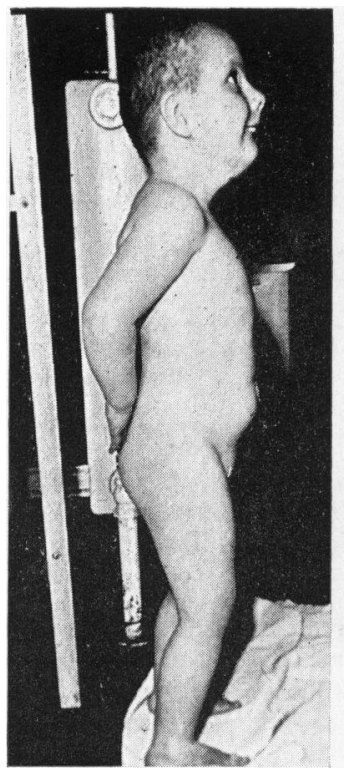

(a)

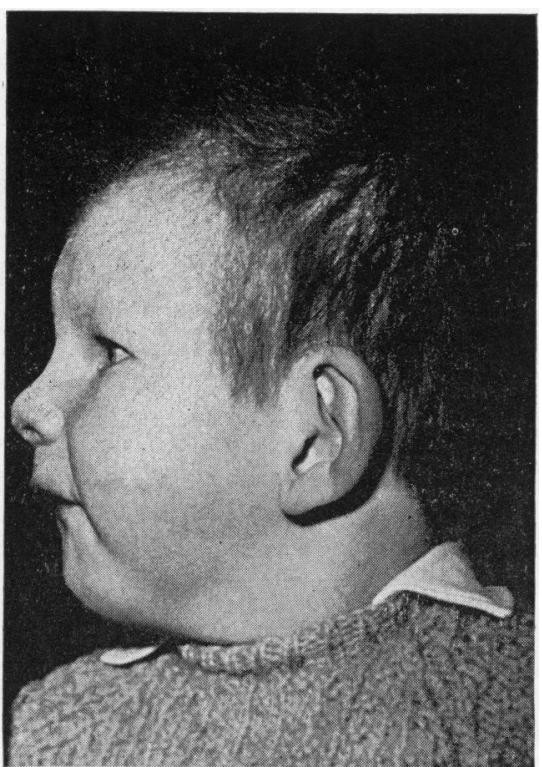

(b)

FIG. 1.-(a) Case 1, aged $5 \frac{1}{4}$ years and (b) Case 2, aged 3 years.

failed to reveal any other cardiovascular defects. The child was not hypotonic and examination of the central nervous system was normal.

Radiological studies. Skull was short based, with small vault (1175 ml. cranial capacity) approximately at the 5th centile (Gordon, 1966). The sella turcica was bridged and small in size, the lateral area $40 \mathrm{sq} . \mathrm{cm}$., and the sella index 1.4. The long bones and the bones of the hands and feet showed ossification compatible with a bone age of 1-1 $\frac{1}{2}$ years; there were a number of disturbed growth lines in the metaphyses.

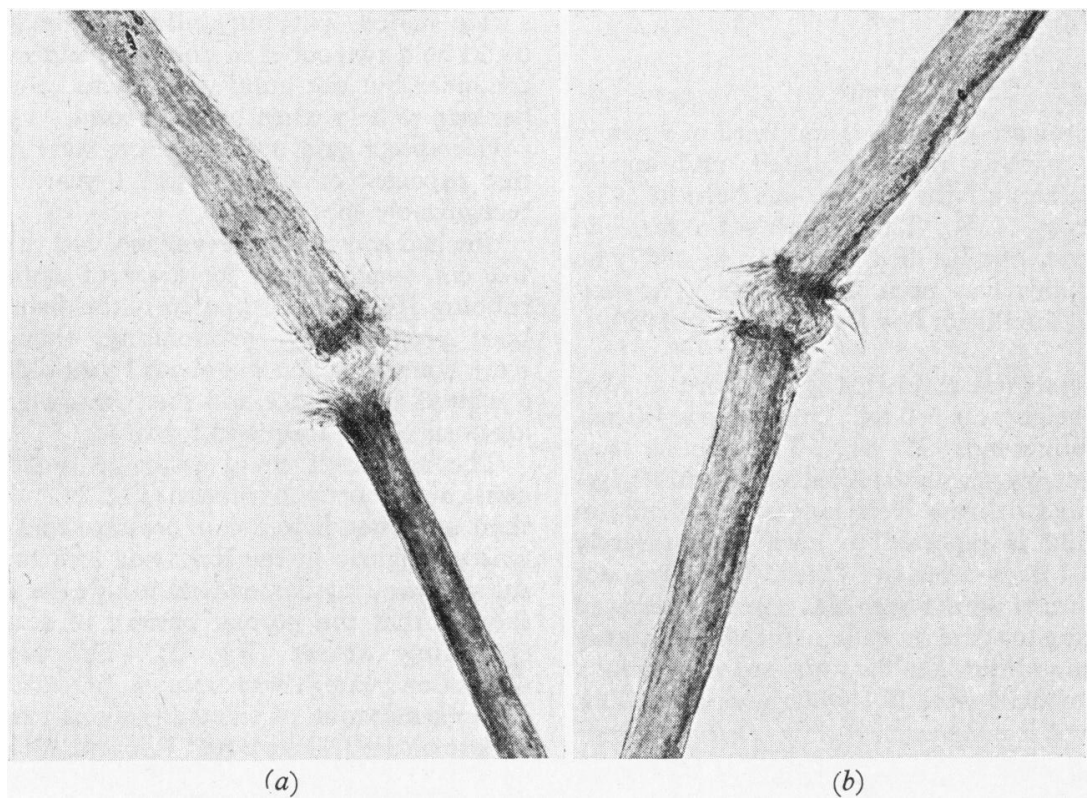

FIG. 2.-Light microscope photographs of the untreated hair. (a) Case 1; (b) Case 2. 


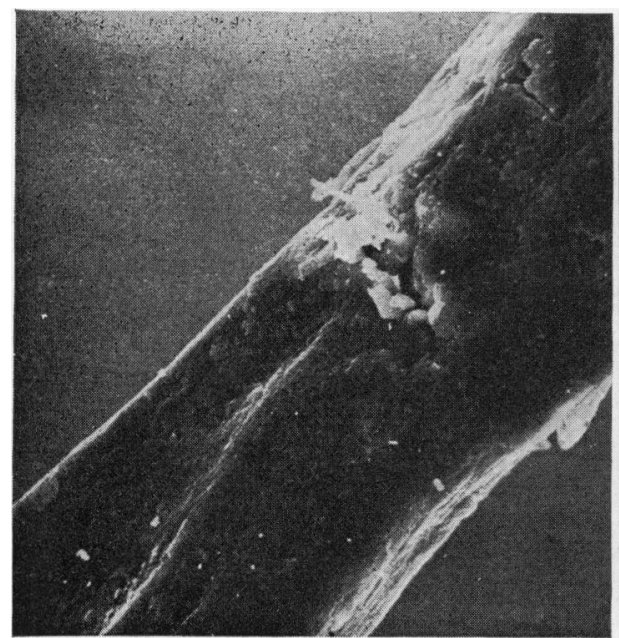

(a)

Fig. 3.-Stereoscan electromicrographs of hair

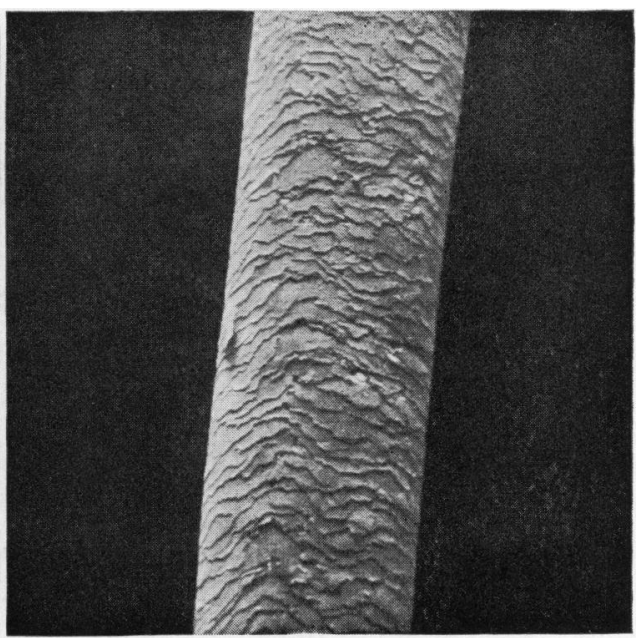

(b)
Dental studies. The enamel of the teeth, though intact, was thin. Aged 5 the deciduous teeth had completely erupted and permanent dentition was well advanced. She displayed marked bruxism.

Chromosome studies. Buccal smears were of normal female type, and seven cells from a lymphocyte culture all contained 46 chromosomes and a normal female karyotype. Dermatoglyphs were normal.

Electroencephalogram. Non-specific abnormalities, with a paucity of faster rhythmic activity and an excess of slow components; there was no asymmetry.

Laboratory investigations. Urinanalysis, serum proteins, and electrophoresis, serum cholesterol, electrolytes, uric acid, bilirubin, alkaline phosphatase, zinc sulphate precipitation test, thymol turbidity, and flocculation tests, SGPT, calcium, fibrinogen, blood urea, blood caeruloplasmin, ESR, $\mathrm{Hb}$, red cell count, white cell count, platelet count, steroids, and $p \mathrm{H}$ were normal.

CSF showed no abnormalities of cell content, glucose, protein, chloride, or colloidal gold precipitation tests.

The serum inorganic phosphate was $4 \cdot 8$ and $5 \cdot 25 \mathrm{mg}$./ $100 \mathrm{ml}$., outside the laboratory's range of $2-4 \mathrm{mg}$. $/ 100 \mathrm{ml}$.

Urinary phenolic acids after a plant-free diet were normal. The urinary amino acids were examined by high-voltage electrophoresis at $p \mathrm{H} 2 \cdot 0$, followed by chromatography in the second dimension using butanolacetic acid-water (12:3:5). Argininosuccinic acid (Koch-Light Laboratories Ltd.) was also run as a standard. The pattern was normal; in particular, the cystine spot was of usual size and there was no trace of argininosuccinic acid. Plasma amino acids were examined by 2-dimensional thin-layer chromatography using systems I and II of von Arx and Neher (1963), after deproteinizing by picric acid or by gel filtration on Sephadex G25 and desalting on Dowex $50 \times 8$ resin. (a) from Case 1 and (b) from a control subject.

The amino acids were present in normal amounts; in particular, the level of glutamic acid was not raised, and cystine was present.

CSF was deproteinized with picric acid, desalted, and subjected to thin-layer chromatography as before. The following amino acids presented clearly defined spots in descending order of intensity-glutamine, alanine, glycine, serine, leucines, glutamic acid, aspartic acid, lysine, phenylalanine, valine, histidine, threonine, arginine, cystine, and asparagine. Proline was also present but not easily compared with the other amino acids.

Faecal amino acids, examined by high-voltage electrophoresis, showed a normal pattern.

Whole blood -SH group levels determined by Ellman's (1959) method were within the normal range.

Chemistry of hair. A specimen of hair was hydrolysed in a sealed tube with $6 \mathrm{~N}$-hydrochloric acid and the resultant amino acids examined by 2-dimensional electrophoresis and chromatography. There was no trace of argininosuccinic acid or of its cyclic anhydrides (Westall, 1960; Ratner and Kunkemueller, 1966). It was noticed, however, that the proportions of the amino acids were different from those from a sample of normal hair so treated. The amino acid compositions of the hydrolysates were determined quantitatively on an amino acid analyser (Table I).

The low cystine content was confirmed using the Shinohara (1936) method, and specific chromatographic searches by Dr. D. J. Raven failed to reveal possible degradation products such as cysteic acid and lanthionine.

Case 2. A.C. was born in Januaty 1964, weighed $3 \cdot 130 \mathrm{~kg}$., his body length was $48 \mathrm{~cm}$.; he was cyanosed at birth and had a considerable ventricular septal defect. At 5 weeks, he had a folliculitis of his face and scalp: 
TABLE I

Amino Acid Analyses of Hair and Hair Proteins: Results expressed as $\mathrm{g}$. nitrogen per $100 \mathrm{~g}$. nitrogen recovered from column (ammonia excluded)

\begin{tabular}{|c|c|c|c|c|c|c|}
\hline & & Case 1 & Case 2 & Control & $\begin{array}{l}\text { Low- } \\
\text { sulphur } \\
\text { Protein` }\end{array}$ & $\begin{array}{l}\text { High- } \\
\text { sulphur } \\
\text { Protein } †\end{array}$ \\
\hline $\begin{array}{l}\text { Asp } \\
\text { Thr } \\
\text { Ser... } \\
\text { Glu } \\
\text { Pro .. } \\
\text { Gly. . } \\
\text { Ala .. } \\
\text { Val . . } \\
\frac{1}{2}-\text { Cys } \\
\text { Met } \\
\text { Ile .. } \\
\text { Leu } \\
\text { Tyr } \\
\text { Phe. . } \\
\text { Lys. . } \\
\text { His . . } \\
\text { Arg. . }\end{array}$ & $\begin{array}{l}\ldots \\
\ldots \\
\ldots \\
\ldots \\
\ldots \\
\ldots \\
\ldots \\
\ldots \\
\ldots \\
\ldots \\
\ldots \\
\ldots \\
\ldots \\
\ldots \\
\ldots \\
\ldots \\
\ldots\end{array}$ & $\begin{array}{r}5 \cdot 41 \\
4 \cdot 26 \\
7 \cdot 33 \\
11 \cdot 02 \\
4 \cdot 41 \\
5 \cdot 68 \\
4 \cdot 32 \\
3 \cdot 67 \\
7 \cdot 67 \ddagger \\
0 \cdot 77 \\
2 \cdot 08 \\
7 \cdot 36 \\
2 \cdot 92 \\
2 \cdot 47 \\
6 \cdot 68 \\
3 \cdot 12 \\
20 \cdot 89\end{array}$ & $\begin{array}{r}6 \cdot 29 \\
4 \cdot 44 \\
8 \cdot 14 \\
11 \cdot 66 \\
4 \cdot 46 \\
5 \cdot 58 \\
5 \cdot 23 \\
4 \cdot 34 \\
6 \cdot 37 \\
0 \cdot 77 \\
2 \cdot 51 \\
7 \cdot 37 \\
2 \cdot 31 \\
1 \cdot 97 \\
6 \cdot 69 \\
2 \cdot 51 \\
19 \cdot 42\end{array}$ & $\begin{array}{r}4 \cdot 03 \\
5 \cdot 62 \\
9 \cdot 06 \\
9 \cdot 75 \\
6 \cdot 26 \\
5 \cdot 22 \\
3 \cdot 27 \\
3 \cdot 43 \\
14 \cdot 23 \\
0 \cdot 49 \\
1 \cdot 66 \\
5 \cdot 49 \\
1 \cdot 87 \\
1 \cdot 25 \\
4 \cdot 55 \\
2 \cdot 63 \\
21 \cdot 21\end{array}$ & $\begin{array}{r}7 \cdot 34 \\
4 \cdot 31 \\
7 \cdot 10 \\
13 \cdot 11 \\
2 \cdot 99 \\
4 \cdot 08 \\
5 \cdot 49 \\
4 \cdot 83 \\
6 \cdot 01 \\
0 \cdot 34 \\
2 \cdot 89 \\
8 \cdot 06 \\
1 \cdot 97 \\
1 \cdot 54 \\
5 \cdot 53 \\
1 \cdot 75 \\
22 \cdot 66\end{array}$ & $\begin{array}{r}2 \cdot 11 \\
8 \cdot 69 \\
10 \cdot 00 \\
7 \cdot 05 \\
10 \cdot 67 \\
5 \cdot 11 \\
1 \cdot 96 \\
4 \cdot 38 \\
22 \cdot 90 \\
1.55 \\
1 \cdot 55 \\
2 \cdot 45 \\
0.58 \\
0.92 \\
1 \cdot 06 \\
2.34 \\
18 \cdot 22\end{array}$ \\
\hline
\end{tabular}

* Human hair, data from Crewther et al. (1966) recalculated.

† Human hair, data from Gillespie and Inglis (1965) recalculated. ¥ The Shinohara method on another sample of hair gave $9.0 \%$ cystine by weight, in agreement with these results.

head circumference was then $32 \mathrm{~cm}$. It was immediately suspected that he was subnormal, and this diagnosis became increasingly apparent during the first year of life. At 9 months he was clearly retarded in growth but not in cardiac failure: head circumference was 41 $\mathrm{cm}$. At 3 years (Fig. 1b) he can walk around holding the furniture and is saying the odd word, but inappropriately. He is less retarded than his sister.

His hair appears to be similar to his sister's and shows the same microscopical features (Fig. 2b). As yet, however, it is less severely affected. His skin is dry. His tongue has had frequent white plaques, he has koilonychia, and has had frequent attacks of flexural eczema. He has always had feeding problems and in particular vomits milk. His teeth are of particularly poor quality, with thin enamel like his sister's, but also with multiple cavities requiring repeated dental attention. His urinary amino acids were normal on examina-

TABLE II

The Family's Blood Groups

\begin{tabular}{|c|c|c|c|c|c|}
\hline & & \multicolumn{4}{|c|}{ Blood Groups } \\
\hline $\begin{array}{l}\text { Father } \\
\text { Mother } \\
\text { Case 1 } \\
\text { Normal sib } \\
\text { Case 2 }\end{array}$ & $\begin{array}{l}\cdots \\
\cdots \\
\cdots \\
\cdots \\
\cdots\end{array}$ & $\begin{array}{l}\text { A } \\
\text { AB } \\
\text { A } \\
\text { AB } \\
\text { A }\end{array}$ & $\begin{array}{l}R h+v e \\
R h+v e \\
R h+v e \\
R h+v e \\
R h-v e\end{array}$ & $\begin{array}{l}\mathrm{CDe} / \mathrm{cde} \\
\mathrm{CDe} / \mathrm{cde} \\
\mathrm{CDe} / \mathrm{cde} \\
\mathrm{CDe} / \mathrm{cde} \\
\mathrm{cde} / \mathrm{cde}\end{array}$ & $\begin{array}{l}\text { Ss } \\
\text { S ? } \\
\text { Ss } \\
\text { S ? } \\
\text { Ss }\end{array}$ \\
\hline
\end{tabular}

Note: $\mathrm{s}$ could not be studied in the presence of $\mathrm{AB}$. All the members were also $\mathrm{MN}$, Kell-ve, Fy (Duffy)-ve. tion. An amino acid analysis of his hair is given in Table I.

Table II gives the family blood groupings and confirms the reported relationships.

\section{Discussion}

The only clear-cut biochemical abnormality demonstrated so far in these 2 patients is in the composition of the hair which has an extremely low cystine content.

Relatively little is known of the chemical structure of human hair itself, but the proteins of sheep wool are being studied intensively by several groups (reviewed by Crewther et al., 1965) and the findings are probably roughly applicable to human hair. Briefly, wool proteins can be solubilized by reduction of the disulphide bridges of the cystine residues at high $p \mathrm{H}$ in the presence of $8 \mathrm{M}$-urea, and the resultant kerateines converted to their S-carboxymethyl derivatives. These may then be fractionated into high-sulphur, low-sulphur, and high-glycine proteins.

The differences in amino acid composition between the patients' hair and normal hair largely parallel the differences between hair proteins of the low-sulphur and high-sulphur groups (Table I). Thus the patients' hair appears to be deficient in high-sulphur proteins.

The cystine content of wool can be changed according to dietary conditions. Infusion of cystine into the abomasum of the sheep can increase the sulphur content of the wool from about 3 to $4 \%$ (Reis and Schinckel, 1964). This involves not only an increase in the proportion of high-sulphur protein, but also a shift within the group of highsulphur proteins to proteins of even higher cystine content (Gillespie, Reis, and Schinckel, 1964; Gillespie and Reis, 1966). The synthesis of these high-sulphur proteins is thus subject to regulation by the availability of cystine.

There does not appear to be a serious defect in cystine transport in our patient, as the levels in the plasma and urine are normal, and there is no evidence of faulty absorption from the gut.

In sheep, copper deficiency decreases the cystine content of the wool (Burley and Horden, 1959; Gillespie, 1964), but it is not known whether this is mediated directly or by decreasing the availability of cystine by altering the gut flora. Copper deficiency in infants has been reported by Cordano, Baertl, and Graham (1964) and Cordano and Graham (1966), but there was no mention of hair changes. Zinc deficiency in animals is accompanied by hair abnormalities and parakeratosis of the skin, but human zinc deficiency has only been observed 
in cases complicated by other nutritional deficiencies.

Thus, the underlying cause of the hair abnormality is obscure. It could be an isolated enzymatic defect, associated 'fortuitously' (perhaps through close chromosomal linkage) with the retardation, or there could be a common underlying biochemical disorder. A detailed chemical investigation of the hair is proceeding.

The physical nature of the hair defect invites comparison with two other inherited diseases associated with mental retardation, argininosuccinic aciduria, and the sex-linked neurodegeneration described by Menkes et al. (1962). In argininosuccinic aciduria there is an hereditary lack of argininosuccinase, which cleaves argininosuccinic acid to arginine and fumaric acid. Argininosuccinic acid is formed from citrulline and aspartate, and is an essential intermediate in the Krebs-Henseleit urea cycle. Hair keratin is an unusual protein in that ornithine is present in the developing hair protein, and this is then converted in situ through citrulline and argininosuccinic acid to arginine (Rogers, 1964). A mild degree of argininosuccinic aciduria has been reported in patients with a form of alopecia, and in one of these cases, which clearly showed trichorrhexis nodosa, argininosuccinic acid was present in the hair (Shelley and Rawnsley, 1965). A defect of argininosuccinase in the hair follicle could also account for the trichorrhexis nodosa in the case of gross argininosuccinic aciduria, but only 5 of the 11 known cases of gross argininosuccinic aciduria have the hair defect, and in one such case there was no argininosuccinic acid in the hair (Levin, 1967). It has been suggested that the absence of argininosuccinase does not apply to the whole body, since affected people can still synthesize urea.

The syndrome of sex-linked neurodegeneration and hair anomalies has a number of features not found in our cases. The disease involves progressive cerebral and cerebellar atrophy and often results in early death. Our patients are in reasonable physical health and are showing slow mental development. Menkes et al. reported high levels of glutamic acid in the plasma but not in CSF. Yoshida et al. (1964) found high levels in the CSF but only slightly raised levels in plasma, while Bray (1965) found no increase in plasma levels but did not examine the CSF. Case 1 showed no excess of glutamic acid in the plasma or CSF.

An interesting finding in this disease is that there was a deficiency of a highly unsaturated fatty acid in the brains of 2 children who died of sex-linked neurodegeneration (O'Brien and Sampson, 1966), the suggestion being that some defect permitted the autoxidation of this substance. A fault in lipid metabolism might conceivably be linked too with the hair defect, since lipid monolayers are believed to play an important part in the orientation of the developing keratin fibres (Rothman, 1964). There was no excessive haemolysis with hydrogen peroxide (Gordon, Nitowsky, and Cornblath, 1955) in Case 1, so that a generalized defect in vitamin $\mathrm{E}$ metabolism can be discounted.

The hair itself is dark in our cases, whereas in sex-linked neurodegeneration the hair is unpigmented. In the cases of Menkes $e t \mathrm{al}$. the hair also showed pili torti, trichorrhexis nodosa, and irregular variations in thickness. In Bray's case the hair was of irregular thickness but trichorrhexis nodosa was not reported. Pili torti and irregular thickness was shown in the cases of Aguilar et al. (1966). Probably all these cases had a similar biochemical defect in the hair but with slightly different morphological manifestations. The possibility of some biochemical features in common with our cases should not be excluded, and an analysis of the hair in sex-linked neurodegeneration is awaited with interest.

\section{Summary}

A brother and sister showing mental and physical retardation and abnormal hair are described. Other members of the family were unaffected and the girl's chromosomes were normal. The hair showed trichorrhexis nodosa, a mild degree of pili torti, and a very irregular surface with partial loss of the normal scale pattern. There was an abnormality of the amino acid composition of the hair, consistent with a deficiency of the high-sulphur group of proteins.

Our thanks are due to Dr. R. Jefferis for the amino acid analysis, to Dr. J. S. Comaish for his opinion on the hair, to Dr. C. Earland for the $x$-ray diffraction and cystine estimations, to Dr. J. M. Gillespie for showing us his results before publication and for his advice, to the Cambridge Instrument Company for the electron microscans, to Dr. H. C. Gunzberg for psychological assessments, to Mrs. J. E. W. A. Trotter for the routine chemical pathology, to Drs. A. G. V. Aldridge and S. R. Wood who stimulated interest in the problems of this family, and to Miss R. E. Mann and Miss M. A. $\mathrm{McD}$ onald for clerical and technical assistance.

\section{REFERENCES}

Aguilar, M. J., Chadwick, D. L., Okuyama, K., and Kamoshita, S. (1966). Kinky hair disease. I. Clinical and pathological features. F. Neuropath. exp. Neurol., 25, 507.

Allan, J. D., Cusworth, D. C., Dent, C. E., and Wilson, V. K. (1958). A disease, probably hereditary, characterised by severe mental deficiency and a constant gross abnormality of aminoacid metabolism. Lancet, 1, 182.

Bray, P. F. (1965). Sex-linked neurodegenerative disease associated with monilethrix. Pediatrics, 36, 417. 
Burley, R. W., and Horden, F. W. A. (1959). Experiments on wool from copper-deficient sheep. Nature (Lond.), 184, 1725.

Chernosky, M. E., and Owens, D. W. (1966). Trichorrhexis nodosa. Arch. Derm., 94, 577.

Cordano, A., Baertl, J. M., and Graham, G. G. (1964). Copper deficiency in infancy. Pediatrics, 34, 324.

—, and Graham, G. G. (1966). Copper deficiency complicating severe chronic intestinal malabsorption. ibid., 38, 596.

Crewther, W. G., Fraser, R. D. B., Lennox, F. G., and Lindley, H. (1965). The chemistry of keratins. Advanc. Protein Chem., 20, 191.

—, Gillespie, J. M., Harrap, B. S., and Inglis, A. S. (1966). Low-sulphur proteins from $\alpha$-keratins. Interrelationships between their amino-acid compositions, $\alpha$-helix contents and the supercontraction of the parent keratin. Biopolymers, 4, 905.

Ellman, G. L. (1959). Tissue sulfhydryl groups. Arch. Biochem., 82, 70.

Gillespie, J. M. (1964). The isolation and properties of some soluble proteins from wool. VIII. The proteins of copperdeficient wool. Aust. F. biol. Sci., 17, 282.

- , and Inglis, A. S. (1965). A comparative study of high-sulphur proteins from $\alpha$-keratins. Comp. Biochem. Physiol., 15, 175. , and Reis, P. J. (1966). The dietary-regulated biosynthesis of high-sulphur wool proteins. Biochem. F., 98, 669.

,-- , and Schinckel, P. G. (1964). The isolation and properties of some soluble proteins from wool. IX. The proteins in wools of increased sulphur content. Aust. F. biol. Sci., 17, 548.

Gordon, H. H., Nitowsky, H. M., and Cornblath, M. (1955). Studies of tocopherol deficiency in infants and children. I. Hemolysis of erythrocytes in hydrogen peroxide. Amer. $\mathcal{f}$. Dis. Child., 80, 669.

Gordon, I. R. (1966). Measurement of cranial capacity in children. Brit. F. Radiol., 39, 377.

Levin, B. (1967). Arginosuccinic aciduria. Amer. f. Dis. Child., $113,162$.

$\longrightarrow$ Mackay, H. M. M., and Oberholzer, V. G. (1961). Argininosuccinic aciduria. An inborn error of amino acid metabolism. Arch. Dis. Childh., 36, 622.
Menkes, H. J., Alter, M., Steigleder, G. K., Weakley, D. R., and Sung, J. H. (1962). A sex-linked recessive disorder with retardation of growth, peculiar hair, and focal cerebral and cerebellar degeneration. Pediatrics, 29, 764.

O'Brien, J. S., and Sampson, E. L. (1966). Kinky hair disease. II. Biochemical studies. F. Neuropath. exp. Neurol., 25, 523.

Ratner, S., and Kunkemueller, M. (1966). Separation and properties of argininosuccinate and its two anhydrides and their detection in biological materials. Biochemistry (Wash.), 5, 1821 .

Reis, P. J., and Schinckel, P. G. (1964). The growth and composition of wool. II. The effect of casein, gelatin, and sulphurcontaining amino-acids given per abomasum. Aust. $\mathcal{F}$. biol. Sci., 17, 532.

Rogers, G. E. (1964). Structure and biochemical features of the hair follicle. In The Epidermis, p. 179 . Ed. by W. Montagna and W. C. Lobitz. Academic Press, New York and London.

Rothman, S. (1964). Keratinization in historical perspective. ibid., p. 1.

Shelley, W. B., and Rawnsley, H. M. (1965). Aminogenic alopecia. Loss of hair associated with argininosuccinic aciduria. Lancet, 2, 1327 .

Shinohara, K. (1936). The determination of thiol and disulfide compounds, with special reference to cysteine and cystine. V. A critical study of cystine determination by sulfite and phospho-18-tungstic acid reagent. F. biol. Chem., 112, 683.

Sikorski, J., and Robson, R. M. (1968). Structure of some abnormal human hairs. (To be presented at Fifth Symposium of the International College of Experimental Dermatology, Palermo, March 1968.)

von Arx, E., and Neher, R. (1963). Eine multidimensionale Technik zur chromatographischen Identifizierung von Aminosäuren. F. Chromat., 12, 329.

Westall, R. G. (1960). Argininosuccinic aciduria: identification and reactions of the abnormal metabolite in a newly described form of mental disease, with some preliminary metabolic studies. Biochem. F., 77, 135.

Yoshida, T., Tada, K., Mizuno, T., Wada, Y., Akabane, J., Ogasawara, J., Minagawa, A., Morikawa, T., and Okamura, T. (1964). A sex-linked disorder with mental and physical retardation characterized by cerebrocortical atrophy and increase of glutamic acid in the cerebrospinal fluid. Tohoku F. exp. Med., 83, 261. 